\title{
SUPREME COURT, InStitutional \\ Change and Authoritarian Regimes: Argentina AND BraziL (1964-1985)
}

Andrés del Río(a)

CORTE SUPREMA, CAMBIO INSTITUCIONAL Y REGÍMENES AUTORITARIOS: ARGENTINA Y BRASIL (1964-1985)

SUPREMO TRIBUNAL, MUDANÇA INSTITUCIONAL E REGIMES

AUTORITÁRIOS: ARGENTINA E BRASIL (1964-1985)

Fecha de recepción: 15 de septiembre de 2017

Fecha de aprobación: 07 de diciembre de 2017

Sugerencia de citación:

Del Rio, A. (2018). Supreme Court, Institutional Change and Authoritarian Regimes: Argentina and Brazil (1964-1985). Razón Crítica, 4, 75-103 , doi: http://dx.doi.org/10.21789/25007807.1280

(a) Doctor en Ciencias Politicas por el Instituto de Estudos Sociais e Políticos da Universidade do Estado do Rio de Janeiro, IESP-UERJ.

Profesor adjunto de Ciencia Política del Instituto de Educação de Angra dos Reis de la Universidad Federal Fluminense IEAR-UFF, Rio de Janeiro, Brasil

https:// orcid.org/0000-0002-7605-7834 andres.delrio@gmail.com 


\section{R E S U M E N}

En el siglo pasado, América Latina experimentó cambios políticos importantes. Muchos países de la región -como Argentina y Brasil-se enfrentaron a duros gobiernos autoritarios, así como a florecientes democracias. En estos dos países, los cambios constantes de los regímenes políticos también provocaron importantes cambios institucionales en el poder judicial, particularmente en la Corte Suprema de Justicia. Este estudio analiza los cambios institucionales de las Cortes Supremas desde una perspectiva comparada. Al observar los casos de Argentina y Brasil, se revisará la trayectoria de ambas Cortes Supremas en un escenario político violento (1964 - 1985). En particular, se analizarán las formas en que tales Cortes fueron alteradas en momentos de regímenes autoritarios. El análisis se centrará en los medios utilizados para modificar cada tribunal y los objetivos de estas modificaciones. Aunque los casos comparten algunas similitudes, es fundamental señalar que cada caso tiene su trayectoria particular. Para entender esto, se analizará la transformación institucional de las Cortes Supremas en Argentina y Brasil desde una perspectiva histórica, siempre teniendo en cuenta los contextos violentos en los que estos cambios suelen ocurrir.

PALABRAS CLAVE: Corte Suprema, régimen autoritário, cambios institucionales, Argentina, Brasil. 


\section{A B S T R A C T}

Over the past century, Latin America experienced important political changes. Many countries in the region -such as Argentina and Brazil- faced both harsh authoritarian governments and flourishing democracies. In these two countries, the constant changes of political regimes also brought important institutional changes in the Judicial Power, particularly in the Supreme Court. This paper will analyze the institutional change of the Supreme Court from a comparative perspective. By looking at the cases of Argentina and Brazil, we will review the trajectory of both High Courts in a violent political moment (1964 - 1985). In particular, we will analyze the ways in which these courts were altered in moments of authoritarian regimes. Our analysis will focus on the means used to alter each Court and the objectives of these modifications. Although the cases share some similarities, it is fundamental to remark that each case has its particular trajectory. To understand this, we will analyze the institutional transformation of the High Courts in Argentina and Brazil from a historical perspective, always keeping in mind the violent contexts in which these changes tend to occur.

\section{KEY WORDS: Supreme Court, Authoritariam regime, Institutional Change, Argentina, Brazil.}

\section{R E S U M O}

No século passado, a América Latina viu importantes mudanças políticas. Muitos países da região, como a Argentina e o Brasil, enfrentaram severos governos autoritários, além de democracias florescentes. Nesses dois países, as mudanças constantes dos regimes políticos também provocaram mudanças institucionais importantes no Poder Judiciário, particularmente no Supremo Tribunal. Este artigo analisa a mudança institucional do Supremo Tribunal numa perspectiva comparativa. Com base nos casos da Argentina e do Brasil, analisaremos a trajetória de ambos os Tribunais Superiores num cenário político violento (1964-1985). Em particular, analisaremos as formas em que esses tribunais foram alterados em momentos de regimes autoritários. Nossa análise se focará nos meios utilizados para alterar cada Tribunal e nos objetivos dessas modificações. Embora os casos compartilhem algumas semelhanças, é fundamental observar que cada caso tem sua trajetória particular. Para entender isso, analisaremos a transformação institucional dos Tribunais Superiores na Argentina e no Brasil a partir de uma perspectiva histórica, sempre considerando os contextos violentos nos quais essas mudanças tendem a ocorrer.

PALAVRAS-CHAVE: Supremo Tribunal, regime autoritário, mudança institucional, Argentina, Brasil. 
"La persona que amas puede desaparecer. Los que están en el aire pueden desaparecer en el aire. Los que están en la calle pueden desaparecer en la calle.

Los amigos del barrio pueden desaparecer, Pero los dinosaurios van a desaparecer". Charly Garcia $1983^{1}$

\section{An Approximation}

South America currently finds itself in an intense process of democratic consolidation and strengthening of the rule of law based on a search for memory, truth and justice in context of its past authoritarian regimes. In such sense, each country deals with their recent violent past on its own way. For the Brazilian case, the creation of a truth commission is a sign of progress towards the pursuit of truth with the ideal of justice in the horizon . In Argentina, the process of investigation and punishment recently implemented and approved by the most important institutions of democracy leaves behind the limits imposed by the laws of Obediencia debida and Punto final. Along this regional development towards the pursuit of truth and justice, the revision of what happened during

1 Artist: Charly García. Song: Los Dinosaurios. LP-Album: Clics Modernos. Year: 1983. "The person you love may disappear. Those in the air can disappear in the air. Those in the street can disappear in the street. Friends in the neighborhood may disappear, but the dinosaurs are going to disappear". 
the latest civic-military regimes is a challenge that involves all of society and that reconstructs the memory of recent tragic processes. Observing and understanding the institutional changes that affected the High Court in a context of terrorism of State is important to deepen our knowledge about this violent period, and analyzing the institutional changes of the High Courts is important to understand the forms of institutional co-optation by the military. The Hight Court has a different institutional participation and production (sentences), harming society in the search for the defense of rights in a moment of need, urgency and violence. In the present work, the trajectories and the institutional changes of the High Courts in Argentina and Brazil during their latest civic-military regimes will be analyzed; in particular, a qualitative and interdisciplinary study will be performed, based on speeches, official documents, legislation, and jurisprudence of the Supreme Courts. Secondary sources to place events in context, especially in the political arena, will be used. The period studied covers from 1976 to 1983 for the Argentinean case, and from 1964 to 1985 for the Brazilian case, taking into account the entire period of the dictatorship. The present work tries to cooperate with the qualitative studies with historical perspective about Latin American Supreme Courts.

\section{Trajectories, Institutional and Change Coalitions}

In general, contemporary theories of institutional development define change as an abrupt break ${ }^{2}$; rather than talking about rupture and discontinuity, we might begin to see the transformative changes that result from the accumulation of a gradual and incremental change (Pierson, 2008). Not only are major changes the product of large shocks, but they can also result from incremental changes

2 When I refer to institutional change in general I think of the "Punctuated Equilibrum Model" PEM of Stephen Krasner (1984, p.242). That is, institutions are characterized by long periods of stability, and periodically they are "punctuated" by a crisis that brings an abrupt institutional change, after which the institutions stabilize again. As Krasner (1984, p.234) points out: "institutional change is episodic and dramatic rather than continuous and incremental". 
with transformative results (Streeck and Thelen, 2005, p. 9). What surprises is the continuities in key characteristics of the institutions despite the context of crisis (Thelen, 2004, p. 7). Institutional survival often involves an active political renegotiation and high doses of institutional adaptation.

The important thing to note is that an institution might exhibit a historical trajectory that is sometimes characterized by surprising continuities across periods of historical breakdowns, but these continuities also have an important and silent process of change through time. As suggested by Thelen (2004), there is no need for a deep division between stability and institutional change; sometimes institutional changes are abrupt, but some others they are not, and eventually they might show a pattern of incremental change through political realignments and renegotiation.

Institution building involves the creation of coalitions and the mobilization of various social and political actors in support of a particular institutional setting. Actors try to interpret or redirect institutions in order to achieve advantages or to pursue their own goals, interests or rules, which might conflict with their interests or those of the institutions themselves. Thus, political renegotiation is crucial to understanding the changes over time as institutions develop and evolve (Thelen, 2004, p. 31-33).

The two cases to be compared have similar institutional structures, although historically they have opted for different paths with unique particularities ${ }^{3}$. The disruption, interference, influence or interruption of the High Court can occur through both formal and informal ways: The former are specific legislation whilst the latter are informal, non-legislative arrangements. During the institutional development of the High Court, such formal or informal arrangements shaped the circumference of the Court; in

3 In a nutshell: The Supreme Court of the United States served as an inspiration for both Argentina and Brazil, which reflects in the construction and in the history of the High Courts in both countries. Moreover, both Argentina and Brazil have a strong legal tradition in the region, and the Supreme Court is the highest institution of a political power as well as acting Constitutional Tribunal in those two countries. Both the Argentinian and the Brazilian Court are guardians of the Constitution as stated in their constitutions themselves (art. 116 in Argentina's Constitution, art. 102 in Brazil's Constitution). Both countries are Federal Republics, and the division of power is established by both Constitutions (art. 1 in Argentina's Constitution, art. 1 in Brazil's Constitution). Also, both countries opted for a presidential system, inspired by U.S. institutions -yet with local characteristics. 
turn, these changes may affect structures or capabilities. For the first case, changing the number of ministers in the High Court, as well as the judges themselves, represents a change in structure; for the latter, changes in capabilities may include changes in the High Court power, such as limiting or increasing the jurisdiction of the Court, among others.

\begin{tabular}{|c|c|c|}
\hline $\begin{array}{c}\text { Means } \\
\text { /Objectives }\end{array}$ & Structure & Capacity \\
\hline Formal & $\begin{array}{l}\text {-Altering number of } \\
\text { members of the HC by } \\
\text { law or constitutional } \\
\text { change } \\
\text {-Taking ministers to } \\
\text { court }\end{array}$ & $\begin{array}{l}\text {-Altering attributions } \\
\text { or jurisdiction by law or } \\
\text { constitutional change } \\
\text {-Creating special tribunals } \\
\text {-Constitutional guarantees }\end{array}$ \\
\hline Informal & $\begin{array}{c}\text {-Political resignations } \\
\text {-Not completing vacant } \\
\text { positions } \\
\text {-Delaying the } \\
\text { confirmation of } \\
\text { designated ministers }\end{array}$ & $\begin{array}{c}\text {-Delaying or not executing } \\
\text { sentences }\end{array}$ \\
\hline
\end{tabular}

Table 1. Means and Objectives of Change in the High Court Font: elaborated from our database ${ }^{4}$.

The structure of the Court is what political scientists usually observe $^{5}$, while scholars of constitutional law and political and institutional history usually study its capacities. In such a way, observing the transformations in both the structures and the capacities at once is necessary for us to deeply understand the characteristics of each case, as well as their commonalities. If we were to compare the Supreme Court with a racing car, changes in

4 The database was created and developed during my doctoral thesis based on the methodology described in the beginning of this work. To deepen the discussion: Del Rio, 2014.

5 There is currently a long production on the judiciary in Latin America, as a case study or compared. In general, the studios observe the structure. As for the field of constitutional law, they marginally observe the structure and focus especially on constitutional rights and sentences. To deepen the debate, see: Del Rio 2014. 
structure would alter the driver, and changes in capacities would affect the engine power. As indicated by Montaigne, different ways lead to the same place; nonetheless, the analysis of how matters to us.

\section{Argentina: Radical Institutional Change}

On March 24, 1976, the Junta of Commanders-in-Chief of the Armed Forces -composed by General Jorge Videla, Almirante Emilio Massera, and Brigadier Héctor Agosti- overthrew the constitutional president Martínez de Perón and took over government. The dictatorship, a juridical-civic-military complex, would rule Argentina from 1976 to 1983 in a self-dominated "Process of National Reorganization." However, differently from previous military regimes, this would be the most perfidious and cruel in its means and would also produce the biggest transformations in society and its institutions. Armed struggle and state terrorism were the unfortunate daily landscape.

As soon as the Military Junta took power, ${ }^{6}$ law n.21.279 (the Statute for the Process of National Reorganization) passed $^{7}$ and dissolved the Congress and the Judicial Power. ${ }^{8}$ Particularly, law n.21.258 concerning the Judicial Power removed all judges of the

6 Law n.21.256, Article 2, established that a superior official of the Armed Forces would be designated by the Military Junta. In brief, four Juntas took power. The first, of longest duration and greatest violence (1976-1980), was composed by Jorge Rafael Videla, Emilio Eduardo Massera and Orlando Ramón Agosti. The second (1980-1981) was integrated by: Roberto Eduardo Viola, Armando Lambruschini, Omar Domingo Rubens Graffigna. The third, leading the Falklands War (1981-1982): Leopoldo Fortunato Galtieri, Basilio Lami Dozo and Jorge Isaac Anaya. The fourth (1982-1983): Cristino Nicolaides, Rubén Franco, Augusto Jorge Hughes. From these Military Juntas, the following official were appointed to head the Executive Power: Jorge Rafael Videla (March 29, 1976 to March 29, 1981); Roberto Eduardo Viola (March 29, 1981 to December 11, 1981); Carlos Alberto Lacoste (December 11, 1981 to December 22, 1981); Leopoldo Fortunato Galtieri (December 22, 1981 to June 18, 1982); Alfredo Oscar Saint-Jean (June 18, 1982 to July 1, 1982) y Reynaldo Bignone (July 1, 1982 to December 10, 1983). 7 These documents were: Acta fijando el Propósito y los Objetivos Básicos para el Proceso de Reorganización Nacional; Acta para el Proceso de Reorganización Nacional; Proclama; Bases para la Intervención de las Fuerzas Armadas en el Proceso Nacional, Estatuto para el Proceso de Reorganización Nacional.

8 Art. $2^{\circ}$ - The Military Junta may, when for reasons of State it considers convenient, remove the citizen that represents the President of the Nation, designating its replacement through a process to be yet determined. Initially, it may also remove or designate the members of the Supreme Court of Justice, the Attorney General, and the Fiscal General of the Fiscalía Nacional de Investigaciones Administrativas.

Art. $9^{\circ}$ - In order to cover vacancies for Supreme Court justices, the Attorney General and the Fiscal General of the Fiscalía Nacional de Investigaciones Administrativas, and the President will validate the designations made by the Military Junta. The designations for judges in lower courts will be made by the President. 
National Supreme Court of Justice (CSJN), the Superior Provincial Courts, the Attorney General, and suspending until further confirmation all of its magistrates and employees. ${ }^{9}$ Article 5 of this law declared: "The magistrates and employees that are designated and confirmed, shall take an oath of observance towards the Basic Objectives fixed by the Military Junta, the Statute for the Process of National Reorganization, and the National Constitution as long as the latter does not oppose the former.” This way, not only were all the members of the Judicial Power suspended until confirmation, but all the newly designated employees had their confirmation dependent upon their acceptance of the statute. Still, most importantly, the Constitution no longer was endowed with the real constitutional supremacy devised in 1853. The kelnesian juridical construction was broken. The Constitution would be applied as a supplement to the new norms dictated by the Military Junta. In the new legislation, no independence remained for the Judicial Power; on the contrary, the new laws diminished the institutional importance of the Judiciary, removing its fundamental attributions. Particularly, the CSJN was no longer a power of the State with political attributions. The Judicial Power, in the words of the report Nunca Más (1984): "became in fact a simulation of the judicial function in order to cover its external image". The Court would comply with and accept the new military norm.

The established legislative complex left all branches of government (Executive, Legislative, and Judiciary) in the hands of the new authorities ${ }^{10}$, i.e., they held the absolute sum of public

\footnotetext{
9 Law n. 21.258. Art. 1: "Cesen en sus cargos los señores jueces de la Corte Suprema de Justicia de la Nación...” Art.2 "Cesen en sus cargos los señores miembros de los Tribunales Superiores de todas las provincias". Art. 3 "Decláranse en comisión a la totalidad de los magistrados y funcionarios del Poder Judicial...”Art. 5 " Los magistrados y funcionarios que se designen y los que sean confirmados, deberán prestar juramento de acatamiento a los Objetivos Básicos fijados por la Junta Militar, Estatuto para el Proceso de Reorganización Nacional y la Constitución Nacional en tanto no se oponga a aquella”. 10 Some of the most remarkable fundamental laws would be: Law 21.258, Judicial Power - all magistrates and employees could be fired. Law 21.260, Public Employees any employee could be removed for reasons of national security or if associated with subversive activities. Law 21.262, Foreign Service - all personnel could be fired. Law 21.264, Ley de represión del sabotaje. Law 21.269, Communist Party, Socialist Workers Party, Workers Party, Trotskist Workers Party, and Marxist-Leninist Communist Party-all activities banned, meeting spots closed, and bank accounts and other goods blocked. Law 21.272, National Security - penalties for acts of violence against military or security personnel, ships, airplanes, or military/security establishments, and for acts of resistence, threats, injuries or attempted acts. Law 21.274, Public Employees - arrangements for dispensing employees. Law 21.275, National Security - right to leave the country,
} 
power doing away with the division of power of the republican system. This brings to mind the opportune reflections of Montesquieu (2004): "There is no liberty if the power to judge is not separated from the Legislative and Executive powers. (...) All would be lost if the same man, or same body of principles, be them of the nobility or of the people, exercised the three powers".

With the military coup, Special Tribunals were created to judge those people included in the Repression Law. The detained were immediately judged without the possibility of being defended by civil lawyers. The judgments were held in secret and a military official acted as the defendant of the detained (Pereira, 2010, p. 199-200). The Penal Code was also altered and the death penalty introduced. Like in other Latin American countries -such as Brazil-, such measure was never applied, although in Argentina it was applied extra-judicially and systematically. The legal plexus in place determined the actions of the CSJN: Military authorities would strictly supervise questions related to individual liberty and penal law, given their supreme objective of National Security.

The coup in Argentina would deeply violate legality more drastically than other military regimes in the region. Learning from the failure of the Chamber of Terror of 1971, the military implemented extreme measures to ensure the duration of its fight against the subversives (Pereira, 2010, p. 205) ${ }^{11}$. They launched an intense struggle against the guerilla and other enemies with no legal restrictions and in an extra-judicial manner. Neutralizing gave way to exterminating, which distanced the possibility of future civil governments for setting free their adversaries; moreover, this annulled the future possibility of a counter-offensive against the

guaranteed by Art. 23 of the Constitution, is suspended. Law 21.276, National Universities - change in rules, partial change in Organic Law 20.654. Decree 9, Associations of workers, businessmen, and professionals - suspension of union activity. Decree 10, "62 organizations" - organization prohibited to act. Decree 11, Confederación General Económica - intervention in the confederation, bank accounts and patrimonial goods blocked.

11 In 1971, the military regime created the Cámara Federal en lo Penal de la Nación, which had a civil nature but shared the same purposes as the military tribunals. It would be nominated the Court of Terror, and its objective was to judge the violent acts of different armed groups opposed to the regime. The Penal Chamber created a fast, specialized, and centralized Court composed by judges who were sympathetic to the regime. With the Law 19.081, the military themselves were apt to investigate crimes that were within the jurisdiction of the Chamber. In two years, over 300 people accused of various political crimes were arrested (Pereira, 2003, p.39). 
militaries. The authoritarian regime tried at all cost an alleged irreversible justice, thus the Supreme Court increased popular distrust in Justice, given the institutional ineffectiveness in sensitive and urgent questions. Institutional changes produced by the coup of 1976 were immediate and profound, and the capacities of the High Tribunal were intensely altered both in shape and extent.

\section{A. Changes in the Composition of the High Court}

When the military government took power, one of its first acts was to declare the compulsory departure of all the members of the Supreme Court of Justice. The removed ministers had been designated by Cámpora with the avail of Juan Domingo Perón in 1973. They represented a political-ideological line that the military junta wanted to leave behind. This way, a completely new Supreme Court would be designated at the beginning of the new government. It is important to note that all of the justices designed in this violent period were not confirmed by the Congress, and thus had no legitimacy. Initially, the Court of this period was composed by: Horacio Heredia, Adolfo Gabrielli, Alejando Caride, Federico Videla Escalada, and Abelardo Rossi. To accede to the position, the selected ministers of the Court should swear, "according to what is prescribed by the basic objectives and the Statute for the Process of National Reorganization and the Argentinean Constitution.” Thus, the architecture and juridical hierarchy of Argentina would be profoundly altered.

During the entire period analyzed, there were modifications in the composition of the High Court. Of the 12 members designated during the regime, Videla nominated nine. It was also during his administration that the deepest period of repression took place: during this initial phase, variations in the Court were important, reaching eight designations in the two first years. The stabilization occurred during the final years of this period. Two judges died while in office (Daireaux and Heredia), and two others would carry out their functions during the entire authoritarian regime (Gabrielli and Rossi). The presidency of the High Court was under the responsibility of Heredia until 1978. After that, 
Gabrielli was the president for the rest of the period. The majority of the designated justices had extensive academic and magistrate experience. The Court was not composed by ministers with long experience in politics; most ministers had a conservative profile (Walker, 2006, p. 776). Many authors comment on the trajectories and characteristics of the ministers of this period (Carrió, 1996, p. 93-94; Ancarola, 1999, p. 137). Nonetheless, without discrediting the hard labor of this Court, the few accepted cases (habeas corpus especially) were minimized by the avalanche of cases in which the Court could not be efficient in the defense of human rights (habeas corpus especially). As we can see, it is not about what they did, but exactly about what they did not do. The cycle of these magistrates ended five days before the beginning of Alfonsín's constitutional presidency, when all the members of the Supreme Court voluntarily renounced (Finkel, 2004, p. 62).

\section{B. Relevant Political Events}

Having the horrors of state terrorism as a background, many events that impacted the military process took place during this period. With the appointment of Martínez de Hoz as Minister of Finance and the implementation of a new economic orientation, ${ }^{12}$ Argentina would leave behind the few structural successes achieved in economic terms, particularly in the industrial sector. The substitution of internal production for importation was the new norm, which damaged national productive structures. The devastating liberal classist economic plan that was implemented was justified for it achieved the political objectives of the tra nsformation project proposed by the Armed Forces (Canitrot, 1980, p. 461).

12 The central dispositions of the economic plan of 1976 were the following: 1) Fixating a new level of real salaries $40 \%$ inferior to the average salary of the previous five years. 2) Eliminating withholdings on exports of agricultural products. 3) Applying a program of progressive reduction of the import taxes (opening the economy). 4) Eliminating subsidies for non-traditional exports, development credit, deficiary social benefit programs (health, housing), real increase in utility rates. 5) Liberalization of exchange and financial markets (financial reform) and the financing of the public deficit through sale of titles in the capital markets. 6) Reduction in spending, in jobs, and government deficit (resizing of the State), re-privatization of companies under state control (principle of subsidiarity of the State). (Canitrot, 1980, p.459). 
In 1978, and with the World Cup taking place in Argentina, terrorism of state and armed struggle was in full swing. There were many complaints demanding to cancel the event given the violations of human rights taking place. That same year, after Argentina rejected Britain's arbitral ruling, the border conflict over the Beagle Canal with Chile reached its tensest moment. A year later, the Inter-American Commission on Human Rights (IACHR) visited Argentina. After two weeks of interviews, the IACHR disclosed the human rights violations perpetuated in Argentina: "The Commission has reached the conclusion that by action or by omission of the public authorities and its agents in the Republic of Argentina, numerous and grave violations of fundamental human rights have been committed during the period covered by this report - 1975 to 1979 - ..." (OEA - CIDH, 1980). In 1980, Adolfo Pérez Esquivel received the Nobel Peace Prize, further exposing human rights violations in Argentina internationally and nationally legitimizing the activities and demands of human rights movements (Acuña y Smulovitz, 1995, p.155) ${ }^{13}$. At the end of the same year, the Pope presented its proposal mediating the border conflict with Chile. Amidst the political, economic, and social crisis of the military regime, on April 2, 1982, Argentinean troops recovered the Falkland Islands. Despite the diplomatic negotiations, conflict broke out. The war ended on June 14 with Argentina's rendition. The fault of the failed generals quickly became the fault of the authorities of the military regime. The sacrifice of the soldiers, victims of the incompetence of their commanders, was converted into the sacrifice of the victims of the regime. As Linz and Stepan show (1996), the military tried to impose a new game, but it failed drastically in its lack of efficiency as well as legitimacy.

As a consequence of the collapse of the authoritarian regime after the loss in the Falklands War, a civil and constitutional government returned to power. No political negotiation with the Armed Forces over the topic of human rights violations preceded the beginning of the new regime. The Armed Forces saw themselves

13 Among the opposition groups and groups in defense of human rights and liberties were: La liga Argentina por los Derechos del Hombre, la Asamblea Permanente por los Derechos Humanos (APDH), el Centro de Estudios Legales y Sociales (CELS), Las Madres de Plaza de Mayo, las Abuelas de Plaza de Mayo, and many others. 
forced to hand back power in the worst conditions they could have imagined: with no guarantees as to how the new political forces would deal with the legacy of the military regime. Differently from other cases in the region (such as the Brazilian case), the politicians had no incentives to negotiate with the defeated military, which had no capacity to influence the political dynamics of the transition of power (De Riz, 1990). The defeat in the war marked a point of inflexion for the regime, and the call for elections quickly took place. Argentina was headed in the difficult task of recovering formal institutions of government, fundamental rights, and political interaction.

\section{Brazil: Gradual and Transformative Institutional Change}

With the coup d'état on March 31, 1964, a civic-military regime that would last 21 years began. Differently from other constitutional interruptions, this coup did not intend to give away the control over Brazilian politics, incorporating the characteristic of permanence. With the new regime, individual freedoms and guarantees were limited. On April 9, the military junta composed by General Artur da Costa e Silva, Liutenant Brigadier Francisco de Assis Correia de Melo, and Vice Admiral Augusto Hamann Rademaker Grünewald dictated the Institutional Act n.1 (AI). In its first article, the act declared: "The Constitution of 1946, the state Constitutions and its respective amendments are maintained with the modifications established in this Act.” The AI n.1 also granted to the military government the authority to revoke legislative mandates, suspend political rights for 10 years, and force the retirement of any person who has made an attempt against National Security ${ }^{14}$. Furthermore, the act determined indirect presidential election to take place on April 11; the mandate shall remain until January 31, $1966 .{ }^{15}$ Article 7 stated that "Constitutional or legal guarantees of vitality or stability

14 In these political scenarios 49 judges were removed (Fausto, 2002, p.467).

15 On April 15, 1964, Castelo Branco was sworn in as President. His mandate would be extended until March 15, 1967, through the Constitutional Ammendment n.9 of July 22, 1964. 
are suspended for six months," and item 4, which particularly affected the Supreme Federal Court (STF), read: "The jurisdictional control of these acts shall be limited to the examination of extrinsic formalities, being prohibited the consideration of the facts that motivated the act, as well as its convenience or opportunity." Nonetheless, this Institutional Act would not be the last.

During his presidency, Castelo Branco would try to maintain respect towards the STF. After certain decisions of the High Court, the hard liners began considering alternatives to this branch of government. In an attempt to appease the spirits of these hard liners, exasperated by certain judicial decisions of the Court ${ }^{16}$, the government dictated AI n.2 on October 27, 1965, affecting particularly the STF. The number of members of the High Court increased to 16; constitutional guarantees of vitality, immobility and stability were suspended, and article 19 declared that: "Shall remain excluded from judicial consideration: I - the acts practiced by the Supreme Command of the Revolution and by the Federal Government, based on the Institutional Act of April 9, 1964, the current Act and on complementary acts; II - the resolutions of Legislative Assemblies and Municipal Chambers that have revoked mandates or declared the impeachment of Governors, Deputies, Mayors or City Counsels, from March 31, 1964 until the date of this Act." Other areas were also affected ${ }^{17}$. The military had left the barracks and were at war against the STF. According to the military perception, the branches of government should walk hand in hand to endorse the continuity and deepen the revolution.

The Constitution of 1946 saw its end with the AI n.4, on December 7, 1966. The act summoned the National Congress to

16 It is important to note that the decisions not only exasperated certain groups within the military, but also many legislators and sectors of the press who saw the High Court in disaccordance with the revolutionary mission. The attacks focused specially on Minister Hermes Lima and Evandro Lins. The habeas corpus conceded to the Governor of the State of Goiás, Borges Teixeira, and to the Ex-Governor of the State of Amazonas, Plínio Coelho, were determining.

17 The AI n.2: installed indirect presidential elections; dissolved all political parties and allowed the creation of new ones; established the presidential power to declare a state of siege for 180 days without consulting the legislature, to intervene in state politics, to declare Congressional recess, to dismiss employees due to incompatibility with the regime, and to dictate law-decrees over matters of national security. Furthermore, the President reserved the right to send constitutional ammendments to Congress, which had 30 days to appreciate the ammendments and approve them with a majority of both legislative houses. 
discuss, vote and promulgate the proposed Constitution presented by the President. According to the military government, "only a new Constitution can guarantee the continuity of the revolution". The current legal mess had gotten out of control, and the new Constitution sought normalization in a sense. In November 1965, the Constitutional Amendment n.16 would profoundly alter the Judicial Power ${ }^{18}$. Federal Justice was institutionalized, as had been announced in the AI n.4. Still, the amendment allowed the STF to judge federal laws or acts by means of the representation of the Attorney General. The constitutional control was strengthened. In addition to the already present diffused control, a concentrated control was instituted (Dias Corrêa, 1987). As Vilhena Vieira suggests:

The problem appears in the form through which active legitimacy was configured, that is, the capacity to provoke the jurisdiction of the Supreme Court. Such legitimacy, attributed with exclusivity to the Attorney General, dismissible ad nutum by the President, became an instrument of little value in controlling the institutional acts produced by the Executive or in its interest." (1994, p. 79).

The new constitutional text came into effect together with the swearing in of Costa e Silva as president, on March 15, 1967. The flaming fundamental text tried to institutionalize and legalize the military regime in a more harmonious way, leaving behind the judicial mutilation of the first years of government. Nonetheless, National Security being its main objective, constitutional guarantees would be profoundly affected, especially individual freedoms ${ }^{19}$. The more the revolution was institutionalized, the more it distanced itself from democracy. Habeas corpus and writ of mandamus were established, although the former would not always be effective when relating to crimes against National Security. The decree-laws

\footnotetext{
18 Some purges in the Judiciary took place in this phase (Pereira, 2010).

19 Regarding the guarantees given to the judges, the new Constitution established, in article 108: "With the exemption of the restrictions expressed in this Constitution, the Judges shall enjoy the following guarantees: [...] III - irreduc bility of salary, subject, however, to general taxes. $\$ 1^{\circ}$ - Retirement shall be compulsory at 70 years of age or for proven disability, and optional after thirty years of public service, in all of these cases with full salaries."
} 
played an important role as a government tool; article 58 established: "The President of the Republic, in cases of urgency or relevant public interest, and as long as it does not result in increases in expenses, may issue decrees with the force of law over the following subjects: I national security; II - public finances". Nonetheless, the Constitution of 1967 would coexist with institutional acts and other legal instruments that appeared over time, constantly eroding its power.

On one hand, the country went through a favorable economic situation (with high concentration of benefits, though); on the other, political opposition, social manifestations (particularly workers and students), and acts of violence multiplied. On October 1968, the Higher Censorship Council (Conselho Superior de Censura) was created (Fico, 2004, p. 212). The military elite noticed that in spite of the measures in place to insure order, these had not produced the expected effect, which created the necessity for deeper measures. In this context, the authoritarian model darkened on December 13, 1968, with the AI n.5. Dictated by President Arthur Costa e Silva, the Institutional Act $n .5$ gave ample power to the government to repress the opposition: the National Congress was shut down (following the Complementary Act N. $38^{20}$ ), democratic mandates were revoked, political rights of any citizen could be suspended for a period of ten years, federal government could intervene in states and municipalities, good could be confiscated in case of unlawful enrichment, and habeas corpus for political crimes against National Security and the socioeconomic order was suspended. After the AI n.5, the authoritarian regime increased repression and would use detention, torture and murder against its enemies or those considered as such. For example, in January 1969 forty-three congressmen were arrested. In July, the Operation Bandeirantes was created, a center for repression located in São Paulo. And in September, the new National Security law, which included the death penalty, was approved.

The Institutional Act n.6 from February 1969 would make the Supreme Court the target one more time. First, the number of ministers was reduced to eleven and, as a consequence, ministers Evandro Lins, Hermes Lima, and Vitor Nunes Leal were pushed

20 Article 1 established: "In the terms of art. 2, and its paragraphs, of the Institutional Act n.5, from December 13, 1968, Congressional recess is declared, from this date." 
into forced retirement. Minister Gonçalves de Oliveira renounced in solidarity. Still, Minister Lafayette de Andrada was removed. The Supreme Court was renovated almost in its entirety. The AI n.6 also altered the capacities of the STF, increased those of the Supreme Military Tribunal, and ratified all constitutional amendments created through Complementary Acts after the AI n.5. According to article four of AI n.6, "All acts performed in accordance with this Act and its Complementary Acts, as well as their effects, are excluded from judicial review". The STF was being pushed aside from its vital functions as an institution. This way, the government avoided jurisdictional control and appreciation of law, although at cost of its legitimacy (Rosa, 1985). The STF had a new institutional status, with a more restricted role and a renovated composition. As Vale (1976, p. 166) suggests: "Since then, especially with the Acts numbers 5 and 6, conflicts ceased, and the Executive-Revolutionary Power found in the Supreme Court an administratively healthy organ, technically agile, [...] but politically dead.” In the same line, Vilhena Vieira (1994) argues that as its capacities were reduced and its ministers altered, the STF no longer offered resistance to the regime.

Still, the modifications continued: on October 17, 1969, Constitutional Amendment n.1 was declared, and would make clear that power would be concentrated in the Executive branch: "Considering that, and given that a parliamentary recess has been decreed, the Executive Federal Power is authorized to legislate over all subjects, according to clause $\S 1^{\circ}$ of article $2^{\text {nd }}$ of the Institutional Act n. 5, of December 13, 1968." The amendment was extensive in the modifications it introduced to the 1967 Constitution. Not few authors admit that it served the purpose of a new constitution. The Amendment n.1 -in addition to the AI n.5-intensified the concentration of power in the Executive and consolidated the legal juridical architecture of the military regime. From the structure of the Constitution of 1946, the modifications of the Constitution of 1967 and the constitutional amendment -or new constitutionof 1969 were introduced. Despite of increasing authoritarianism, certain liberal forms of governmental organization were not completely altered -the legislative and judicial powers remainednor were citizen rights completely annihilated, although these would be restricted to its maximum. 
With the swearing in of Médici as head of the Executive Power, a duality was momentarily installed. The economic development had important consequences in the process of legitimization of the violent regime. As Gaspari (2002, p. 18) indicates, "The economic miracle was simultaneous to the repression and the armed struggle. Both real, they coexisted and denied each other". Between the governments of Costa e Silva and Médici, repression would reach its maximum expression in the armed struggle: during this period, there were more than 300 disappeared, 25,000 political prisoners, 10,000 exiles, and over 7,378 people judged by military courts for political crimes (Pereira, 2003). ${ }^{21}$

With the Geisel government, there was an attempt at a process of normalization, but the economic crisis altered the initial plans. The military regime started to lose support from the middle and high classes, which had previously sustained it. In 1974, the regime met an electoral, and in 1977 the constitutional amendment n.7 increased the capacities of the STF (Dias Corrêa, 1987, p. 17).

The process of political opening presented many scenarios, yet the military questions would be predominant. This way, the process was set to be a slow one. In June 1978, AI n. 5 was lifted, and in October of that same year the constitutional amendment n.11 brought back parliamentary guarantees and reorganized the party system. In March 1979, Figueiredo assumed the presidency. On August 22 of that year, the Amnesty Law was approved; the Law was restricted to those involved in political crimes, ${ }^{22}$ although later, with the support of the Supreme Court, it was converted into a bilateral amnesty that benefited in an ample, general and unrestricted manner the members of the authoritarian regime ${ }^{23}$. The Law

21 In brief but clear words, Soares (1994, p.29) shows that: "facts confirm that political repression was concentrated in 1964, and later in the years from 1969 to 1973. This repression was distributed throughout all sectors of national life, including military, civilians, and parts of the State. However, regarding the question of the dissapeared, the killed, and the abused, the majority these acts appears in the second moment. More than this, we want to call to attention the fact that what changed in this second phase was the target of repression, involving sectors of the social and cultural national elites, the improvement of methods, the institutionalization and organization of the repressive system..."

22 The Amnesty Law n.6.683-1979 exposed the internal disagreement amongst the military on the liberal measures taken during the period of transition (Soares, D'Araujo e Castro, 1995). Currently, the amnesty law is being strongly debated, recently reaching the STF in a lawsuit demanding its revision. The Supreme Court's early arguments were not in favor of the revision of the law.

23 As Abrão (2011, p. 123) shows: “... the social pressure for the investigation of crimes 
passed through a process that was controlled by the regime, giving it a meaning of political-social agreement to co-opt the fact that it had only partial legitimacy. This supposed legitimacy was strengthened with time, based on the legality of the law conceded by the Supreme Court. The prolonged transition towards redemocratization in Brazil, as well as the negotiation of diverse sectors and the military, would have serious impact in the future regarding the punishment for crimes committed during this period. With relation to the transition and action of the STF, Vilhena Vieira (1994, p. 81) states: "The Supreme Court collaborated towards the transition in the rhythm established by the agenda of the government. In diverse episodes in which the Supreme Court was sought after, the litigants had their pretentions frustrated by a court submissive to the will of the military." At last, as we may observe during the course of the period being analyzed, the civic-military regime constantly altered the capacities of the High Court until they achieved to create a Supreme Court in accordance with the power and objectives of the illegitimate government. These modifications in capacities were gradual, albeit cumulative, thus succeeding to institutionally transform the role of the High Court within the national political scenario.

\section{A. Composition of the STF During the Military Regime: 1964 - 1985}

With the military regime in place, the Supreme Federal Court slowly turned into an uncomfortable institution for the objectives of the revolution. In spite of the fact that part of the ministers recognized the respect of President Castelo Branco towards the court, it was during his presidency that interventions in the court began. This trajectory deepened until the new regime achieved to create a Supreme Court in accordance to its wills; differently from the Argentinean case, however, the modifications in the High Court happened gradually, not abruptly. In order to calm the spirits of

increased, which led the Judiciary - note: controlled by the regime - to systematically and interpretevly expand the spectrum of the scope of the Law, considering the crimes committed by agents of the State as "related to political crimes," and, moreover, applying the Law even to crimes occured post-1979, outside its temporal validity (such as the Riocentro case in 1980), under the guise of the principle of "national pacification'". 
the harsher sectors of the military, Castelo Branco implements the Brazilian Court Packing, increasing to 16 the number of members of the court with the AI n.2 of October 27, 1965. Thus, five ministers were designated and sworn in on November 25 of the same year. This number was maintained by the Constitution of 1967. The designated ministers were Adalício Coelho Nogueira, José Eduardo do Prado Kelly, Oswaldo Trigueiro de Albuquerque Mello, Aliomar de Andrade Baleeiro, and Carlos Medeiros Silva. According to Minister Hermes Lima, the designations had honored the court, granting it independence and quality (Vale, 1976).

Nonetheless, the increase in number of members and the designation of ministers did not cause the effect the military had expected. On December 13, 1968, based on the Institutional Act n.5, three ministers were forced into compulsory retirement, leaving their positions in January, 1969; in solidarity, Minister Antonio Gonçalves de Oliveira resigned in February of that very year. Minister Antonio Carlos Lafayette de Andrada also resigned in the same period. The AI n.6 re-established the number of ministers to eleven. The three ministers who were compulsory removed were Evandro Lins, Hermes Lima, and Vitor Nunes Leal. All had had an active participation in defense of the Constitution.

During the authoriatian regime, 32 ministers were designated to the High Court, of which 12 were designated during the first four years of the regime. Undoubtedly, the intervention over the STF had succeeded in renovating its composition, although these changes in structure were simply complementary to the changes in the institutional role of the High Court established by the legislated implemented during the regime.

Regarding the Presidents of the High Court, it is worth paying attention to the three first. These were the only ministers nominated in democratic moments: Minister Ribeiro da Costa designated by Linhares, Minister Luiz Gallotti by Dutra, and Minister Gonçalves de Oliveira by Juscelino Kubitschek. It was during these presidencies that the STF experienced its greatest interferences and changes, and these presidents did not fail to show their dissatisfaction. After these presidencies, the role of the STF was diminished as was the importance of the president of the High Court. Definitely, the modifications in the structure of the court deepened with time: on one hand its size was modified, and on the other its composition 
was changed. Once the military achieved to have the type of Supreme Court they wished for, institutional changes in this area were minimal. Given the strategic importance of these institutional changes in the structure of the High Court, it is important to note that followed two fundamental characteristics: In the first place, these changes were gradual and never radical or abrupt like in the Argentinean case; secondly, they were complementary to the institutional changes in the capacities of the High Court. It might be for this reason that the modifications in the structure were gradual, since they were complementary and cumulative with the objective of achieving a solid institutional transformation.

\section{Conclusions}

Throughout the institutional development of the Supreme Courts of Argentina and Brazil during their respective military regimes, constant changes happened over time. Some were the result of an accumulation of gradual and incremental changes (Pierson, 2008), whilst others were the product of abrupt institutional change. As these cases show, major changes can happen alongside a strong sense of institutional continuity. After re-democratization, these continuities become important authoritarian legacies in democracy ${ }^{24}$. Given the extensive possibilities of types of changes, this paper observed changes in structure as well as in capacity of the High Courts, always within the political and historical context in which they happened. The result is an analysis of the development of the Supreme Court through its institutional changes during authoritarian regimes.

To begin with, this paper noted the difference in the temporal period studied in each case: the civic-military regime lasted seven years in Argentina, while in Brazil the regime lasted three times as long, for 21 years. This temporal difference suggests different

24 To deepen the debate of authoritarian legacies in democracy, see for the Brazilian case: Del Rio, Andrés. Ditadura, Democracia e Justiça Transicional no Brasil: Trajetória e Legados do Supremo Tribunal Federal. Dados [online]. 2014, vol.57, n.4. For the Argentinean case, see: Del Rio, Andrés. La dictadura argentina en el banquillo: la trayectoria de la justicia y punición a los responsables por los crímenes de lesa humanidad. Política, Globalidad y Ciudadanía. Universidad Autónoma de Nuevo León Vol 1 Núm 1. enero-junio, 2015. 
meanings. Nonetheless, what is important about this difference is that it clearly exposes the degree and pace of the institutional changes in each case. It shows the Brazilian gradualism and the Argentinean rupture. It was during a period of five years that Brazil went through the institutional changes that finally transformed the institutional architecture of the Supreme Court and distilled its institutional role. If we consider five years in the Argentinean case, we are referring to over $70 \%$ of the military regime. In this case, the main institutional changes already had been implemented in less than six months.

In both cases, institutional changes produced through modifications in the capacities or structure transformed the role of the High Court. In this sense, the court was an institution devoid of strength or tools vital to its function. Moreover, in both cases, this lack of strength profoundly affected the role of the Supreme Court in the defense of human rights, in the context of systematic human rights violations as a consequence of state-sponsored terrorism. The courts did not channel social demands for human rights violations, rejecting habeas courps and obstructing investigations. A fundamental role was absent in a moment of extreme need. For each case, this violent context has unique characteristics: in Brazil, it was important for the regime to maintain a certain democratic disguise; in Argentina, the military opted for illegality in its pure state, and the extrajudicial execution materialized in the forced disappearance of citizens. As a similarity, in the realm of human rights both cases exhibit a High Court with little importance and ineffectiveness regarding the defense of basic rights. In order to enrich our comparative perspective, we will analyze the modifications produced in the High Courts of each case study, noting similarities and individualities.

\section{A. Changes in Capacities}

In the Brazilian case, with the coup of 1964, the new regime established a dictatorship with a democratic and legal disguise. There were many changes in the capacities of the High Court, each with a different depth and extent. The attributions and capacities arising from the Brazilian legislation, Constitutional and national, 
were modified repeatedly. These ended up molding an STF with little power and diminished in its institutional role within the political system. For example, the Institutional Acts n.5 and 6 (1968 and 1969) seriously affected the STF. The AI n.6 established, in its article 4, that: "All the acts practiced in accordance with this Institutional Act and its Complementary acts, as well as its effects, are excluded from any judicial appreciation." In addition, while the capacities of the court were increased at certain points, these had limited effects. The amendment of 1977 is a clear example. In particular and exceptional cases, there were sentences that were not executed by the government. In Brazil, the stability of the structure of the STF was given ultimate importance, but in order not to run any risks with its members, governments altered its capacities and even its institutional role. These changes in capacities were the principal strategy in the Brazilian case, and also served as a type of insurance for changing political regimes.

A remarkable characteristic of the Brazilian case was the modifications in capacity, which happened in a gradual and constant form. The rhythm of the changes was gradual and cumulative, and with time these changes solidified into important institutional transformations affecting the institutional role of the Supreme Court. The Brazilian gradual, cumulative, and constant changes were implemented in many different ways: institutional acts, decrees, constitutional ammendments, and even through new constitutions. This de facto formality or legality was lacking legitimacy. The military governors were determined to maintain at least a façade of legality (Acuña y Alonso, 2001, p. 17). This judicial bipolarity of the regime (de facto legislation with democratic pretensions) would be extinguished with the implementation of the AI n.5, which legally unmasked the ruling authoritarism.

In the Argentinean case, the development of the High Court followed a different trajectory in which the interventions in its capacities were not the main or only feature. Institutional breakdown and modifications of the hierarchy of the legal structure did alter the capacities of the High Court. The coup of 1976 is good example of a moment when the changes in capacities were deep, and also especially extreme. Law No. 21.258 of 1976, art. 5, declared that: "The magistrates and employees that are designated and confirmed shall take an oath of compliance towards the Basic Objectives as stated by 
the Military Junta, the Statute for the Process of National Reorganization, and the National Constitution, as long as the latter is not oppose to the former documents." In this sense, the modification of the Kelsen legal pyramid led to extreme abrupt changes in the Argentinean Supreme Court, giving this Court a new, smaller, institutional role. The loss in attributions multiplied the feeling of a functional and weak institution. The lack of defense of human rights by the Court was an example of its real incapacity as a judicial institution. During the period in which massive disappearances took place, the judicial power became an almost irrelevant resource. The modifications in the capacities of the High Court were emphatic and abrupt, eliminating the necessity for constant readjustments. Gradual processes were not needed, given the rupture in legality produced by the coup of 1976. But the Supreme Court was not the only institution affected: it followed the same luck as all the other state institutions, as a result of the de-prioritization of national legislation.

\section{B. Changes in Structure}

When changes in structure were analyzed, we focused especially in the modifications in the size of the High Court and in its composition. In the Brazilian case, with the implementation of the AI n.2 of October 27, 1965, the number of ministers increased from 11 to 16 . This was considered an attempt at a Brazilian Court Packing. Five ministers were designated, taking office on November 25 of that same year. The total number of ministers was maintained by the Constitution of 1967. On February 1, 1969, the Institutional Act $n .6$ reduced from 16 to 11 the number of members in the Supreme Court. As a consequence, three ministers were forced to retire: Evandro Lins, Hermes Lima, and Vitor Nunes Leal. Following that, Minister Gonçalves de Oliveira resigned in solidarity and Minister Lafayette de Andrada was removed. It is important to note that all of the removed ministers had been designated during democracy. Thus, the Supreme Court was renovated almost in its entirety, leaving only Justice Gallotti as a minister who has been designated during a democratic period. The military pushed away those whose interpretations did not meet revolutionary ends. Through a gradual process, the Court was purified of the ministers 
that bothered the illegitimate government. The increase or decrease in number of ministers of the High Court was implemented by the civic-military regime jointly with the designation of new members or forced removal of others. In this sense, as these constant and gradual changes in structure accumulated, they ended up producing significant transformations in the institution of the Supreme Court and renovating it almost in its entirety. Small, constant modifications had a transformative power and produced important change (Pierson, 2008), which in the end re-oriented the objective of the Brazilian High Court.

On the other hand, in the Argentinean Case, the Supreme Court was composed by five ministers, a number that was kept constant throughout the entire period. This apparent and alleged stability in the size of the High Court had a direct cause: with the arrival of the civic-military government, all of the ministers were forcedly removed from their position. Thus, the characteristic in focus is the radicalism in the illegal and informal removal of the Supreme Court Justices. The complete renovation of the members of the High Court was thus an effective measure to achieve the desired institutional re-orientation sought by the authoritarian regime. It is important to note that this forced and compulsory renovation of ministers was a strategy used by de facto Argentinean regimes in other points in history: 1955, 1966, and 1976 (case in question). The Argentinean case presents a particularity: with the return to democratic regimes, the (de facto) judges willingly resigned. This occurred in 1958, 1962, 1973 and in 1983. It is important to keep in mind that political trial against supreme justices had only been used once before the military regime in point. During the first Perón government, four members of the CSJN were sent to trial, although one of them would resign before the end of the process. In this context, the radicalism, depth, and swiftness in the changes in structure of the High Court after the coup of 1976 is notable.

Both cases show an important issue related to the new designations and compulsory removals: with new designations as well as with the obligatory removals, the ministers were not subject to a formal process of designation and removal nor to a process of political trial, deepening problems of institutional legitimacy. 


\section{Unique and Shared Characteristics}

As seen, every actor tries to interpret or re-direct institutions to achieve advantages towards the fulfillment of their own objectives or interests. Observing the changes in coalitions is important for institutions rely on them (Thelen, 2004, pp. 31-33). In the Brazilian case, the Supreme Federal Court was an institution that was constantly re-directed and re-molded in a gradual manner to meet the new necessities of the authoritarian coalition in power. In this case, the accumulation of small institutional changes ended up significantly transforming the institutional role of the Supreme Court in the national scenario. Meanwhile, in the Argentinean case, radicalism was the main feature in the measures taken to re-design institutions to achieve the interests of the authoritarian regime. Breakdown immediately provoked the desired institutional changes. There was no gradualism in the execution of these changes; on the contrary, even the end of the military regime would be abrupt. In these authoritarian processes, each country had particular characteristics, although in both cases the outcome was a profound change in the High Court. Finally, with the return to democracy, each Court faced new challenges, as a result of the institutional inter-relations of democratic processes.

\section{References}

Abrão, P., (2011). A Lei de Anistia no Brasil. As alternativas para a verdade e a justiça. Acervo, 24(1), 119-138.

Acuña, C., y Alonso, G. (2001). La reforma judicial en América Latina: un estudio sobre las reformas judiciales en Argentina, Brasil, Chile y México. Ponencia presentada en el VI Congreso Internacional del CLAD sobre la Reforma del Estado y de la Administración Pública, Buenos Aires, Argentina, 5 - 9 de Noviembre.

Acuña, C., y Smulovitz, C. (1995). Militares en la transición argentina: del gobierno a la subordinación constitucional. In: Acuña, C. La Nueva Matriz política argentina. Buenos Aires: Nueva Visión.

Ancarola, G. (1999). Reflexiones sobre la función política de la Corte Suprema en los gobiernos de facto. Academia Nacional de Ciencias Morales y políticas. Doctrina 1999, Tomo XXVIII. 
Bohoslavsky, J. (2015). ¿Usted también, doctor?: Complicidad de jueces, fiscales y abogados durante la dictadura. Buenos Aires: Siglo Veitiuno Editores.

Canitrot, A. (1980). La disciplina como objetivo de la política económica. Un ensayo sobre el programa económico del gobierno argentino desde 1976. Desarrollo Económico, 19(76), 453-475.

Carrió, A. (1996). La Corte Suprema y su Independencia. Buenos Aires: Abeledo-Perrot.

Comisión Nacional sobre la Desaparición de Personas (CONADEP). (1984). Nunca Más. Informe de la CONADEP, Buenos Aires.

D’Araujo, M., Glaucio, A., Dillon, S. y Castro, C. (org.). (1994). Os Anos de Chumbo: a memória militar sobre a repressão. Rio de Janeiro: RelumeDumará.

De Riz, L. (1990). Argentina: El comportamiento electoral durante la transición democrática 1983-1990. Documentos CEDES/41. Buenos Aires: CEDES.

Del Rio, A. (2014). El desarrollo Institucional de la Corte Suprema de Justicia Nacional y del Supremo Tribunal Federal. Trayectorias comparadas desde el establecimiento a la redemocratización. Curitiba, PR: CRV.

Dias Corrêa, O. (1987). O Supremo Tribunal Federal, Corte Constitucional do Brasil. Rio de Janeiro: Forense.

Fausto, B. (2002). Historia do Brasil. São Paulo: editora da Universidade de São Paulo.

Fico, C. (2004). Além do golpe: a tomada do poder em 31 de março de 1964 e a ditadura militar. Rio de Janeiro: Record.

Finkel, J. (2004). Judicial Reform in Argentina in the 1990s: How Electoral Incentives Shape Institutional Change. Latin American Research Review, 39(3) 56-80,

Gaspari, E. (2002). A ditadura escancarada. Vol.2. Coleção As Ilusões Armadas. São Paulo: Companhia das Letras.

Krasner, S. (1984) Approaches to the State: Alternative Conception and historical Dynamics. Comparative Politics, 16(2), 223-246.

Linz, J. J., y Stephan, A. (1996). Problems of democratic Transition and consolidation. Southern Europe, South America, and Post-Communist Europe. Baltimore - London. The Johns Hopkins University Press.

Montesquieu, C. (2004). Del espíritu de las leyes. Buenos Aires: Ediciones Libertador.

Pereira, A. (2003). Political Justice under Authoritarian Regimes in Argentina, Brazil, and Chile. Human Rights Review, January-March, 2747, doi: 10.1007/s12142-003-1024-7

Pereira, A. (2010). Ditadura e repressão: o autoritarismo e o estado de direito no Brasil, no Chile e na Argentina. São Paulo: Paz e Terra.

Pierson, P. (2008). Big, Slow - Moving, and... Invisible. Macrosocial Processes in the Study of comparative Politics. In: Mahoney James, Rueschemeyer, Dietrich (Editors) Comparative Historical Analisys in the Social Science. Cambriedge University Press. 
Secretaria General, Organización de Estados Americanos (OEA), Comisión Interamericana de Derechos Humanos (CIDH). (1980). Informe sobre la situación de los derechos Humanos en la Argentina. Abril.

Soares, A., y D'Araujo, M. (org). (1994). 21 anos de regime militar: balanços e perspectivas. Rio de Janeiro: Editora da Fundação Getulio Vargas.

Soares, A., D’Araujo, M. y Castro, C. (org.). (1996). A Volta aos quartéis: a memória militar sobre a abertura. Rio de Janeiro: Relume-Dumará.

Steinmo, S., Thelen, K., y Longstreth, F. (1992) Structuring politics: Historical instituonalism in comparative analysis. Cambridge University Press.

Streeck, W., y Thelen, K. (2995) Beyond Continuity. Institutional change in advanced political econommies. Oxford University Press.

Thelen, K. (2004). How Institutions Evolve. The Political Economy of skills in Germany, Britain, the United States and Japan. Cambridge University Press.

Vale, O. (1976). O Supremo Tribunal Federal e a instabilidade políticoinstitucional. Rio de Janeiro: Civilização Brasileira.

Vilheira, O. (1994). Supremo Tribunal Federal: Jurisprudência política. São Paulo: Editora Revista dos Tribunais.

Walker, C. J. (2006). Toward Democratic consolidation? The Argentine Supreme Court Independence and the Rule of law. Florida Journal of International Law, 18(3), 745-806. 